\title{
History of Mosque Architecture in Lahore
}

\author{
Dr. Muhammad Yusuf Awan \\ Dean, School of Architecture and \\ Planning \\ University of Management \\ and Technology \\ Lahore, Pakistan \\ Beenish Mujahid \\ Department of Architecture \\ School of Architecture and Planning \\ University of Management \\ and Technology \\ Lahore, Pakistan \\ Dr. Saima Gulzar Mahwish Zafar \\ Department of Architecture \\ Research Scholar \\ School of Architecture and Planning \\ University of Management \\ and Technology \\ Department of Architecture \\ University of Engineering \\ Lahore, Pakistan. Lahore, Pakistan.
}

\begin{abstract}
The mosque has served as one of the most important institutions of the Muslim world at all times. This paper outlines the religious function of a mosque and explains the architectural scheme to fulfill the required function. Numerous historical mosques have been built by the Muslims in different parts of the world. These are famous on account of their attractive architecture, attention to detail and wider horizontal as well as vertical arrangements. The city of Lahore possesses a heritage of different civilizations, which include Pathan, Mughal, Sikh and British. A number of historic mosques built from the Pathan to the British period were surveyed to analyze early mosque architecture. The study of the prominent congregational mosques, before the establishment of Pakistan and the post-independence mosques shows influence from the Prophet's (SAW) Mosque in Madina-al-Munawara. An analysis concludes that historical mosques were magnificent and a great source of inspiration for the post-independence mosque architecture. Thus, there is a need to conserve them with all their original architectural and decorative features for future generations.
\end{abstract}

Keywords: Mosque, Dome, Minaret, Arches, Courtyard

\section{Introduction}

Prophet Muhammad Ibn Abdullah (SAW) (570-632) introduced Islam in Arabia and this monotheistic religion spread to the continents of the world within a short span of time. ${ }^{1}$ There are five basic rukans (elements/pillars) of Islam, i.e., kalma (declaration of the faith in Allah and His Prophet Muhammad (SAW), namaz (daily prayer five times during the day, a submission to Allah), roza (fasting as per prescribed instructions), zakat (payment of a part of one's savings for the benefit of the poor/less blessed people of the society), and hajj (a visit to the house of Allah in Makkah in a prescribed manner at a particular time of the year). The function of namaz/prayer is performed in a building called mosque or masjid in open as well as in covered areas. Therefore, the concept and process of offering a prayer should be properly understood in order to discuss the architectural features and building details of the mosque. 


\section{Salat/Namaz}

Salat is the name of obligatory prayers, which are performed five times a day to establish and strengthen the direct link between the worshipper and Allah. There is no hierarchical authority in Islam and no priests; so a learned person who knows the Quran leads prayers in the congregation. The five prayers contain verses from the Quran and are said in Arabic, the language of revelation. Prayers are offered at their specific timings, which vary a little throughout the year with changes according to sunrise and sunset timings.

It is binding upon every Muslim to perform the prayer. Although it is preferable for men to pray in congregation, it can be done alone as well. Narrated by Abdullah Bin Umar, Allah's apostle said, "The prayer in congregation is twenty seven times superior to the prayer offered by person alone." ${ }^{2,3}$ Prayers are offered in four different situations, i.e., individually or alone, in a gathering on Friday, in a gathering at the time of eid festivals (twice a year), and in international gathering at the time of hajj in Makkah-al-Mukarma, Saudi Arabia, once a year.

There are three categories of prayer areas considering the functionality of the prayers and capacity requirement. The first one is small/mohallah/neighborhood mosque. It is conventionally located within walking distance from the residences and meant for offering the five daily prayers. It consists of a room $/$ hall with a mehrab in the center on the Qibla side wall.

Secondly, the jamia mosque for Friday prayer has a bigger capacity to house people from the whole community or many neighborhoods. It has a bigger hall with a mehrab as well as a minbar for khutaba. The facilities for toilet and ablution are mandatory and are generously provided.

Third is the eidgah, ${ }^{4}$ which is a mosque for offering eid prayer. This generally consists of an open ground/area with ablution and toilet facilities. The architectural planning allocates certain areas to the category of the prayer area. Lastly, the fourth category is of hajj prayer, which is offered at Makkah only. This research paper focuses on development of Friday Mosques in the city of Lahore.

\section{Mosque}

The Arabic word "Masjid" originates from the Nabatean word "masgheda," used in pre-historic times. It means "place of prostrations." 2 These days, the word mosque is commonly used and it corresponds to the Arabic word masjid. Since the $10^{\text {th }}$ century, every large congregational mosque is known as jami $i^{5}$ mosque, while the word masjid is generally used for small mosques.

Various styles of mosques evolved from the basic architectural requirements and aesthetic vocabulary needed to meet the liturgical requirements. Mosque builders worked through the waqf system to generate funds for the mosque in addition to the government sector. The government presently controls the construction of mosques in many Muslim states under the ministry of auqaf. 


\section{Mosque Orientation}

The central theme that is used for the design of any mosque is its axis, which is the principal determinant of the structure. Makkah is the focal point for all the Muslims of the world as their prayers are directed towards Qibla (which means direction). For the Muslim community, the Kabah, situated in Makkah, is the holy city of pilgrimage of the Muslims. The origin of Kabah dates back beyond the time of Muhammad $(S A W)$. It is in shape of a cuboid and hollow from inside. It is made of stone and has been rebuilt many times throughout history. ${ }^{6}$

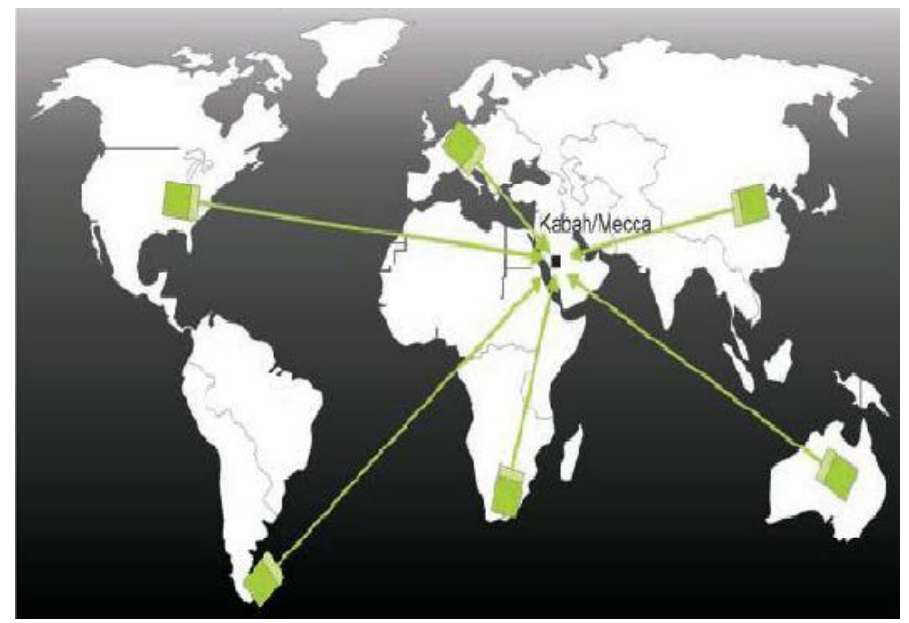

Figure 1: Mosque Qiblah Direction

The direction of prayer is the most important feature of all the mosques and there are a number of methods to calculate the accurate angle for Qibla which is one of the key deciding factors regarding the layout of the mosque on the site. One of the most commonly used methods is the great circle method. ${ }^{7}$ The calculation for the great circle is based on the geometrical angle that is between the meridian (north - south line) and the great circle passing through the Kabah and the place of origin. So the direction of Qibla for the city of Lahore is 10 degrees south of west ${ }^{8}\left(260.31^{\circ}\right.$ from True North).

\subsection{The Prophet ( $S A W$ )'s Mosque in Madina-al-Munawara (622 A.D.)}

The mosque emerged in different forms, scale and proportions bearing a central position in Islam and the Islamic community. It is important to study the origin of mosques and their transformation with the passage of time to understand the various stages and the evolution of congregational mosques over time.

The first congregational mosque was built by Prophet Muhammad (SAW) adjacent to his house in Madina-al-Munawara. The plan of the mosque is square, enclosed by brick and stone walls. Palm sticks and mud were used to cover the enclosure, and palm trunk columns supported the roof structure. ${ }^{9}$ The Qibla direction was marked with the stone block that served the correct orientation of prayer. 
The Prophet $(S A W)$ enlarged the mosque in 629. Along the side of the mehrab, a minbar was placed which was made of wood in the form of a seat and two steps. This was used by the Prophet $(S A W)$ for delivering the khutba. The call for prayer, i.e., azan, was recited by standing on a platform in the open courtyard.

This particular small scaled mosque also provided shelter to people, served as discussion platform for social and political issues, and educational forum for all in addition to other multipurpose activities like healthcare, etc. The mosque had a simple shape, which allowed its expansion throughout history, along with the growing need for bigger space. In 707, a concave mehrab was added in the Prophet's $(S A W)$ Mosque. Nowadays, the total area of the mosque is 100 times larger than the original one. It has the capacity to accommodate up to half a million worshipers.

The spatial and temporal evolution of mosque plans were always developed from the basic and simple generic layout introduced by Prophet $(S A W)$ comprising of a enclosure and a standard prayer hall.

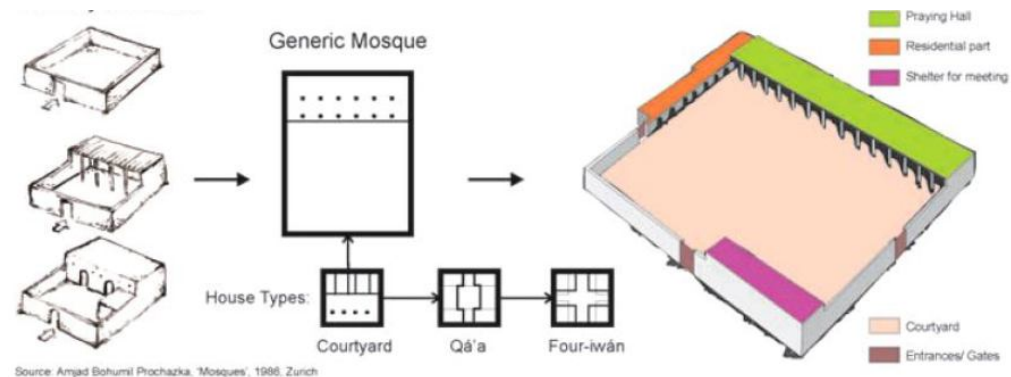

Figure 2: Different Stages of First Mosque Development in Madina-al-Munawara

\section{Mosque in Islamic History}

Mosques have played a very important role in the history of Islam during the early periods. The Friday or Jummah Mosques were located near the market place for early access and to attract more people who would remain busy in their business activities otherwise. The mosque was not only a place to offer prayer but also acted as a community and administrative center, and provided all sorts of communal functions. ${ }^{10}$

Unfortunately, the present day use of the mosque has been limited to offering of rituals, i.e., namaz, aitekaaf and reciting the Holy Quran. Additional functions, which were regularly performed in mosques in the past, are described as the following:

- For sorting out community problems and seeking opinion of people on burning issues

- As an educational institution from school to university level as well as a place for research

- For imparting elementary education to young children

- As a place to encourage and hold literary discussions and debates 
- To deliver lectures, hold seminars and invite questions and criticism

- Served as a place to impart justice through qazis for all sort of cases

- As a state guest house to entertain delegates/visitors from outside areas

- As a clinic to offer treatment and medicines to sick people

- Holding of nikkah/ marriage ceremonies

- For storage of weapons

- Shelter for the homeless and travelers

- A place to distribute food to the needy or hungry

- As a bait-ul-maal for the disbursement of staff salaries

- As a place for depositing and distribution of maal-e-ghaneemat (war booty)

\section{Mosques of the Subcontinent}

Islam was introduced in the subcontinent in $711 \mathrm{CE}$ following the victory of the Ummayyad army leader Muhammad Bin Qasim over Raja Dahir, the ruler of Sindh at that time. Earlier, many attempts had been made by the Muslim Arab army to conquer the northwestern part of the Indus Valley, i.e., Kashmir to the Arabian Sea, but it was Muhammad Bin Qasim who finally succeeded.

Muhammad Bin Qasim introduced mosque architecture in all the major areas he conquered by building mosques in such areas. The oldest mosque found from that period (727 A.D.) is in Bhambore. This mosque was made of limestone blocks with mud mortar. Other cities or towns where mosques were erected are Multan, Deybul, Sehwan and Depalpur. However, all these mosques diminished with the passage of time and their architectural features were not recorded. A little evidence of the Muslim mosque architectural characteristics was available only in the areas of Deybul and al-Mansurah through the archaeological remains that were unearthed there.

\section{An Analysis of Historic Mosques in Lahore}

For the assessment of the historic mosque architecture in Lahore, an analytical study of mosques built during the Pathan to British Period has been done. New mosques which were constructed after independence took inspiration from the historic mosques, and these mosques have been a constant source of motivation for future mosques.

\section{a) The Pathan Period (1030-1526)}

The use of overlapping arches and sloped thick walls are the most unique architectural characteristics of this period. Niwin Mosque and Sheran Wali Mosque depict this period. These mosques are magnificent in character and show work of great solidity.

\section{i. Niwin Mosque}

The Lodhi family constructed Niwin Masjid in 1460. This mosque is important because its structure was built 25 feet below the level of the city. No mosque in the world is built at such a level because usually mosques are considered superstructures that are constructed above the ground level. The Lodhis not only con- 
structed the mosque but they were also responsible for its renovation and maintenance.

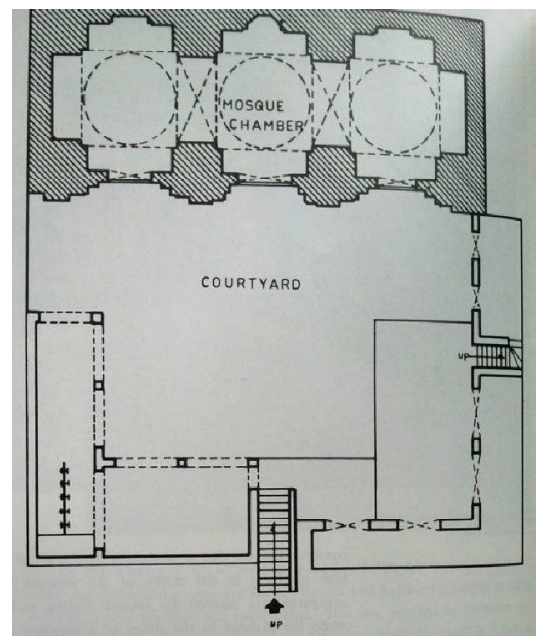

Figure 3: Plan View of Niwin Mosque

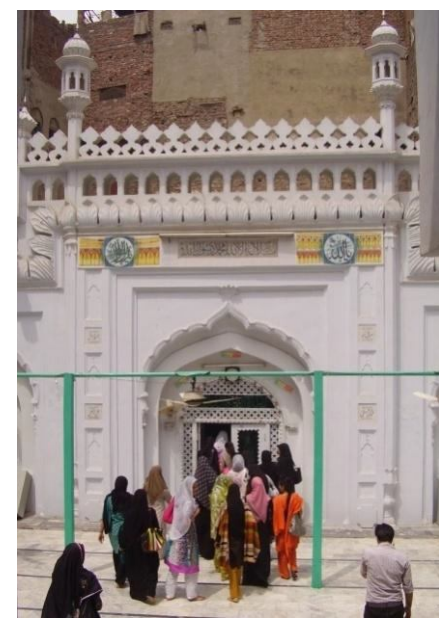

Figure 4: Prayer Hall Entrance of Niwin Mosque

\section{b) Mughal Period (1526-1857)}

The most eminent Islamic buildings in the Indian subcontinent were constructed by the Mughal Emperors. The Mughal builders followed Hindu and Persian architectural style. One of the most important architectural characteristic of the Mughal Period is the use of mosaic patterns which were constructed in various colored stones or glazed tiles. The features of Mughal architecture that inspired the whole world comprised of generously used overlapping arches, lofty minarets, Persian style domes and large vaulted roofs. The examples of great mosques constructed in this period include Moti/Pearl Mosque, Maryam Zamani Mosque, Wazir Khan Mosque, Badshahi Mosque and Golden Mosque

\section{i. Pearl Mosque (1598)}

The Pearl Mosque, also known as Moti Masjid, is located inside the Lahore Fort. It was built during the reign of the Mughal Emperor Shah Jahan. White marble has been used in its construction. The mosque is erected on an elevated platform that is 6'-9" high and reached by climbing eleven steps. ${ }^{11}$ The courtyard having an area of 55'-9" x 32'-2" is overlaid with marble slabs. The two-aisle prayer hall is divided into five compartments. Each compartment has similar arched opening. Pietra Dura ${ }^{12}$ ornamentation is done on the parapet wall with marble inlay. The three bulbous double domes have lotus cresting and are finished with precious marble. 


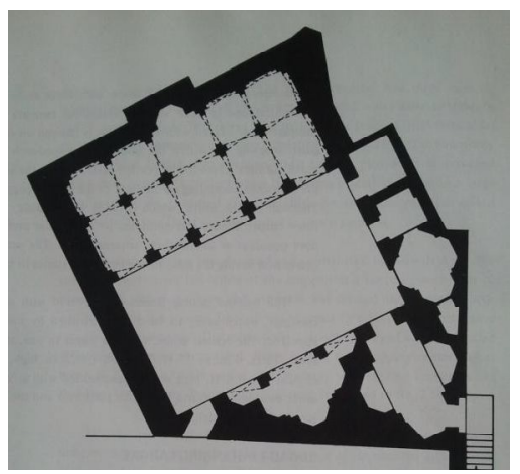

Figure 5: Plan View of Moti Masjid, Lahore

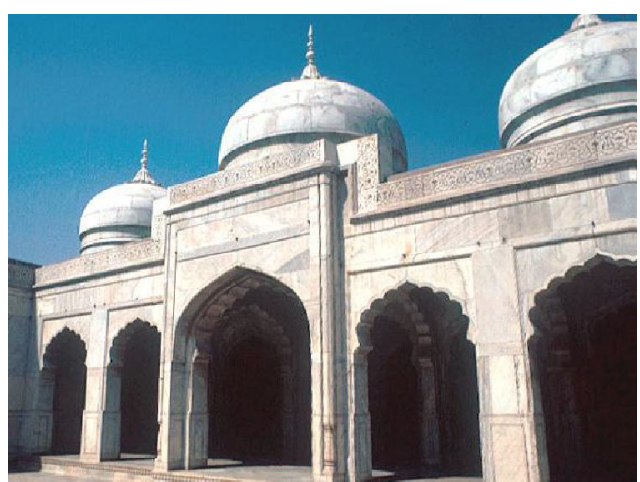

Figure 6: East Façade of Pearl Mosque, Lahore

\section{ii. Maryam Zamani/Begum Shahi Mosque (1614)}

Mughal Emperor Jahangir built this mosque in honor of his mother Begum Maryam Zamani. Located in the Walled City of Lahore, the mosque covers an area of $135^{\prime} \mathrm{X} \mathrm{127}$ ', and is famous for two important architectural features. It includes the practice of double domes in the prayer hall and fresco painting done on the interior surface. The massive mosque structure is constructed with brick masonry. The architectural style marks a transitional period between the two periods, i.e., Pathan and the Mughal. The characteristic of gigantic domes is taken from the old Pathan period mosques. However, the construction style seen in the gateways, the balconies and the hujras are reflective more of Mughal architecture. A lofty aiwan gateway is present at the north entrance of the mosque. The courtyard measuring an area of $128^{\prime} \mathrm{X} 82^{\prime}$ is situated a few feet below the level of the road.

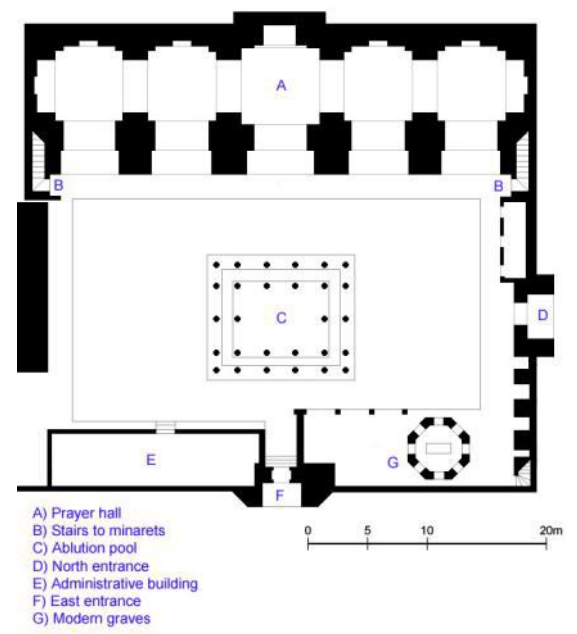

Figure 7: Plan View of Maryam Zamani Mosque 


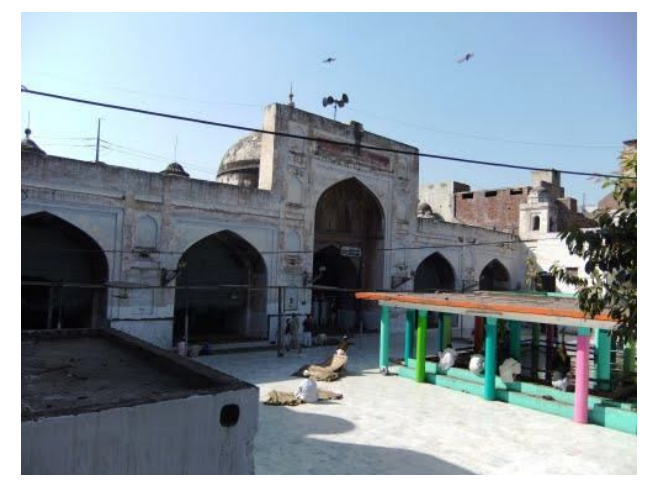

Figure 8: External View of Maryam Zamani Mosque

\section{iii. Mosque of Wazir Khan (1634)}

This colorful mosque was built by Hakim Ilmuddin, the famous Governor of Punjab during the reign of Mughal Emperor Shah Jahan. The fabulous mosque is erected on an elevated podium with steps leading to the attractive entrance present on the East side. The arched entrance is ornamented with floral designs patterns and artistic calligraphy. ${ }^{13}$ The domed entrance portal opens into a spacious courtyard. There is a traditional clear water tank in the middle of the courtyard for the ablution of the believers. The four 100' high octagonal minarets were provided at each corner of the quadrangle with spiral staircase inside. The rows of cells/room hujras, served for practicing different creative skills and $m a$ drassa, were provided in the enclosure wall.

The mosque's prayer hall is divided into five spaces with an opening into the vast courtyard through an arched doorway. Each compartment has a domed roof. The central compartment dome and arched entrance rise higher than the flanking domes and arches on either side.

The Wazir Khan Mosque is a key example of prolific ornamentation of excellent calligraphy, polychromatic glazed tiles, colourful paintings and flawless tazakari (brick-imitation). ${ }^{14}$ Buono type fresco work can be seen on the fancy wall paintings. These types of paintings are set when the plaster is still loose and not allowed to gain strength so the colours mixed with water-and-lime or only water go deep into the surface. The prominent feature of this type of painting is that it cannot be detached when dry, unless the entire wall plaster is removed.

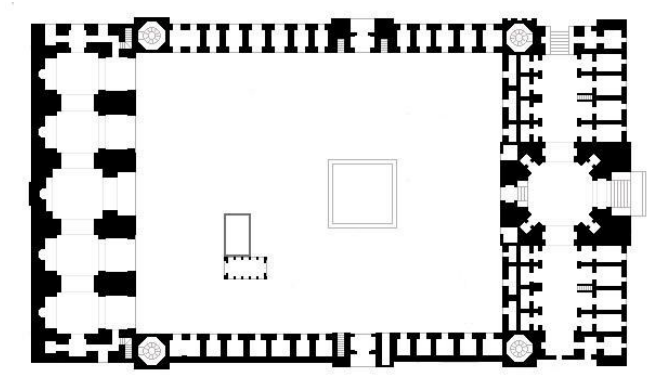

Figure 9: Plan View of Wazir Khan Mosque 


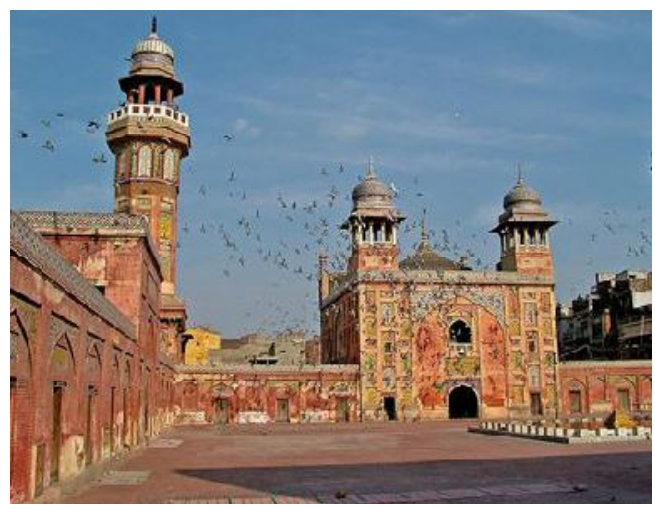

Figure 10: Wazir Khan Mosque Courtyard

\section{iv. Badshahi Mosque (1673)}

Mughal Emperor Aurangzeb constructed one of the most spacious mosques of his time situated to the West of Lahore Fort. Badshahi Mosque, a monumental mosque constructed with red sandstone is a blend of strength, harmony and grace. It is approached by a flight of 22 steps as it is situated on a raised platform. The double-storey entrance covered with a central vault opens into the mosque courtyard. The main prayer hall is located on the West side of the courtyard while the rooms or hujras surround the remaining three sides. The courtyard is divided into two levels: upper level and lower level. The lower level accommodates the water tank on the eastern side.

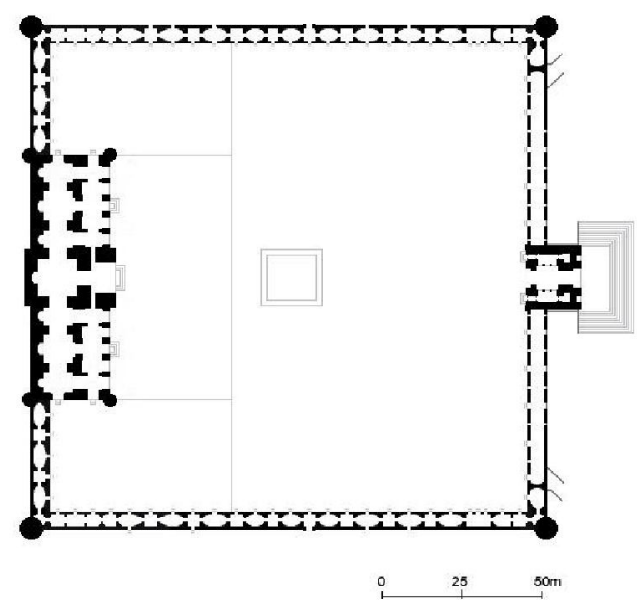

Figure 11: Plan of Badshahi Mosque 


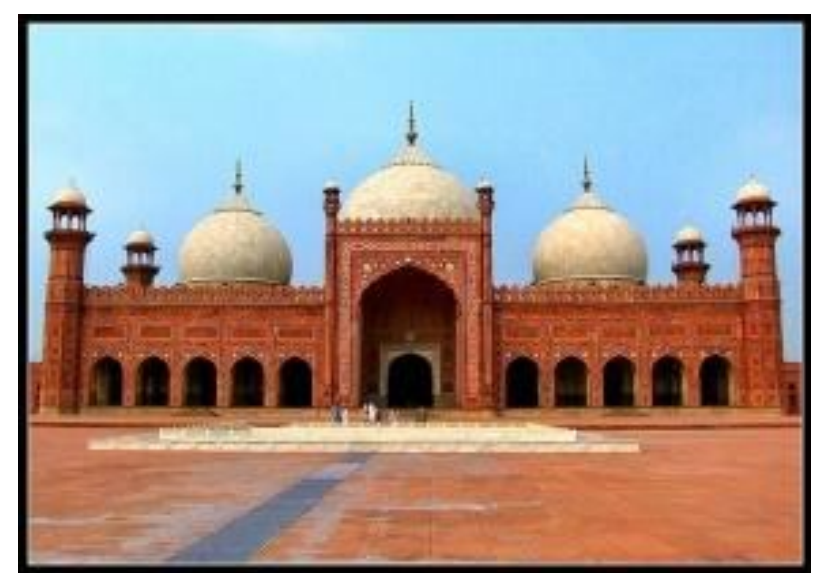

Figure 12: Prayer Hall Entrance of Badshahi Mosque

The main prayer hall is located on the West side. The roof of the prayer hall has three white marble domes that are ornamented with pinnacles of brass. It has numerous arched entrances; the central arch of the gateway is wide in comparison with other arches and is ornamented with red sandstone inlaid with white marble.

\section{iv. Sonehri Masjid/ Golden Mosque (1753)}

In 1753, Architect Nawab Bikhri Khan constructed the Golden Mosque in Kashmiri Bazar, Lahore. It is also known as the Sonehri Masjid. There is a covered entrance port along the South and the stone steps lead to the courtyard of the mosque. The magnificence of the mosque was enhanced more after the construction of a new gateway on the East. Three large gilt domes are used for covering the arched entrances, the central dome being larger than the other. There is a parapet of small, open and narrow arches over the arched entrances that are surmounted by a row of small ornamental gilt domes. Water tank is also provided in the center of the courtyard for ablution.

\section{b) Sikh Period}

Moran Mosque (1809) and the Nawab Imamud Din Khan Mosque (1849) are the best examples of mosques constructed in this period. Ranjit Singh, Maharaja of the Sikh Empire, converted all the holy places including mosques into workspaces for the production of firearms and ammunitions.

\section{c) British Period}

Lahore came under the rule of British Empire after the Sikh. They used the mosques as military garrisons. Karim Bakhsh Mosque and Sirdar Khan Mosque are few examples.

\section{i. Sirdar Khan Mosque}

According to historians, Kanhaiya Lal and Latif, Sirdar Khan Baloch constructed this mosque in 1858. It is situated in the area of Mozang, Lahore. The original mosque had a three level centralized prayer hall. The hall was crowned by a number of petal-like ornamented domes. There were heighted towers at the cor- 
ners of the periphery wall. Sirdar Khan planned to build four tall towers but he died before the complete construction of the wall. Although the mosque was incomplete, it was impressive in his time, and its towering minarets could be seen from a great distance. The periphery walls and two corner minarets were demolished later on, leaving only the central prayer hall that is now painted in white.

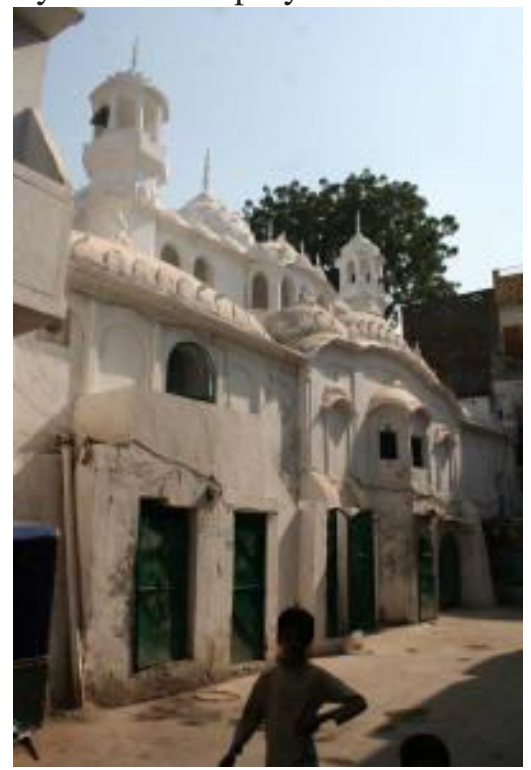

Fig 13: Mosque of Sirdar Khan in Mozang

\section{An Analysis of Post Independence Mosque Architecture in Lahore}

After independence, there was a growth in the trend of mohalla mosques, as people at that time did not feel any need of a grand mosque in Lahore.

\section{Jamia Hajveria / Data Ganj Bakhsh Mosque (1981)}

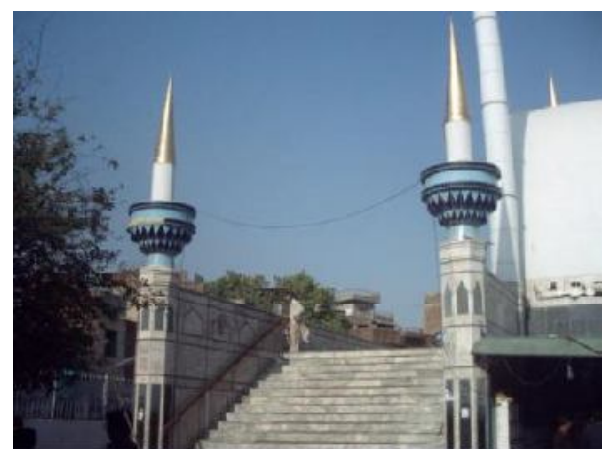

In 1978, Army and Chief Martial Law Administrator, General Muhammad Ziaul-Haq advised the Muslims to spend their lives according to the Islamic order. He also arranged a design competition for the Mosque of Data Ganj Bakhsh. The site given to the designers was adjacent to the Data Ganj Bakhsh Mazar. The proposal given by Naqvi \& Siddiqui won the competition. It was proposed to be Lahore's second biggest mosque after the Badshahi Mosque. 


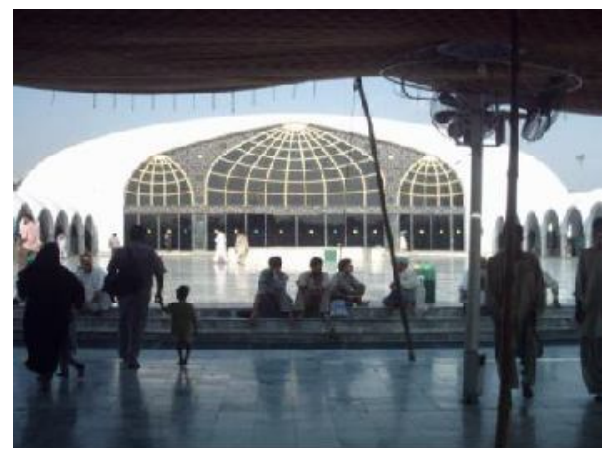

Figure 14: Flight of Steps at the Entrance Ganj Bakhsh Mosque

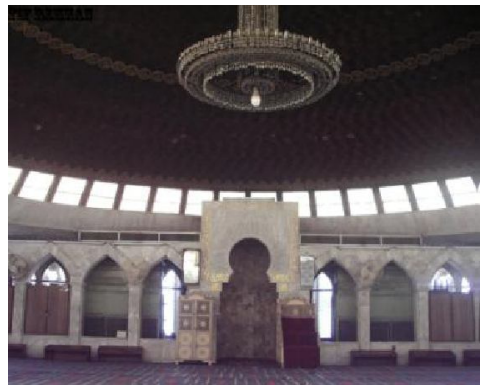

Figure 15: Data Ganj Bakhsh Mosque from Inside

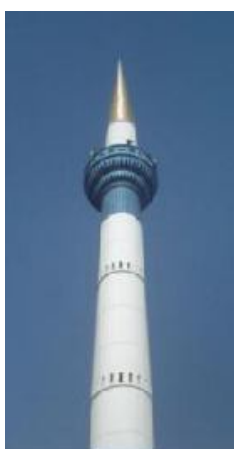

Figure 16: Heighted Minaret of Ganj Bakhsh Mosque

The huge mosque was constructed on a square grid of 13'-4" x 13'- 4" and the main prayer hall covers an area of 80' -0" X 120'- 0'. The mosque has two 191'0 " high conical minarets with golden top. The large window with stained glass and ceramic panelling which is present within the mosque was designed by Jay Bonner who is famous for contemporary and traditional Islamic ornamentation. Stained glass was manufactured in London and the hand-painted 18'- 6" wide and 14'-6" high ceramic panels were produced in Turkey. 


\section{ii) Masjid-e-Shohada (1970)}

As a memorial of the Pakistani and Kashmiri martyrs of the 1965 Pakistan-India War, a mosque was built on the Mall Road, Lahore in 1970. The structure has heighted minaret and domical roof. There is a whole cladding of white marble on exterior walls and the carved marble nets have been used for the window coverings. The prayer hall is raised on a high platform. There are two ablution areas, one in the basement and other in the open area of the mosque complex.

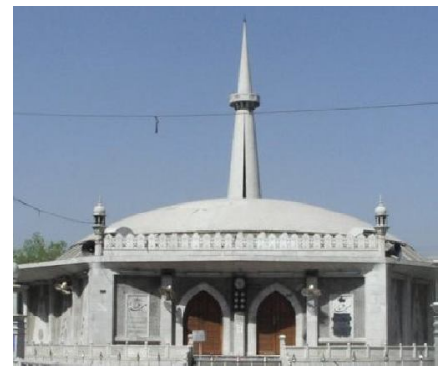

Figure 17: Masjid-eShohda

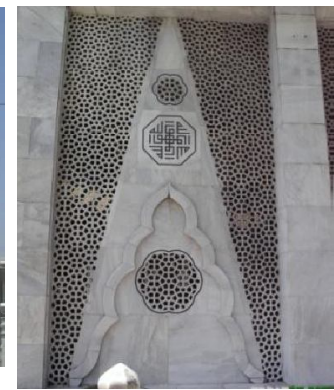

Figure 18: Façade of Masjid-eShohda Showing Use of Screens

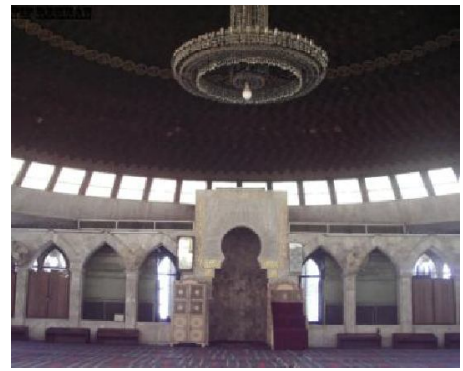

Figure 19: Interior View of Prayer Area of Masjid-eShohda

\section{ii. Mosques Inspired from Masjid-e-Nabwi}

The most popular formula followed in Lahore's Jamia Mosques is the use of a singular dome and one minaret. Majority of the city mosques have a green colored dome, which shows their influence from the dome of the Prophet's Mosque in Madina-al-Munawara. It seems that the reason behind this tradition of mosque style is the religious affiliation with the Masjid-e-Nabvi. Furthermore, the construction of this type of dome is simple as compared to that of the Mughal periods curved domes.

The best examples of this architectural style are the Jamia Masjid Tajal-e-Kaba located at Jail Road, Lahore, and Masjid-e-Khizra that is situated at the crossing of Mall Road and Canal Road, Lahore, as shown in the figures 21 and 22.

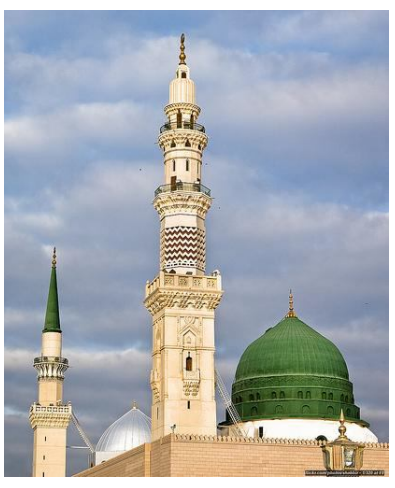

Figure 20: Masjid-e-Nabwi

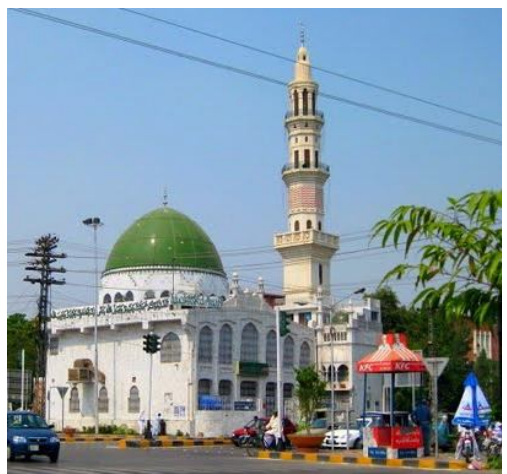

Figure 21: Jamia Masjid Tajal-e-Kaba, Jail Road, Lahore 


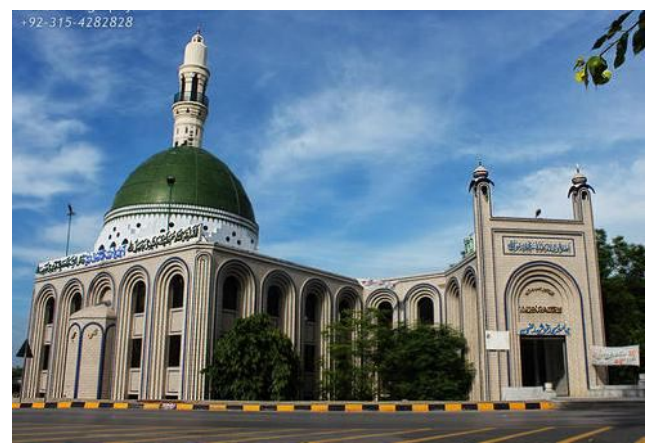

Figure 22: Masjid-e-Khizra, Mall Road, Lahore

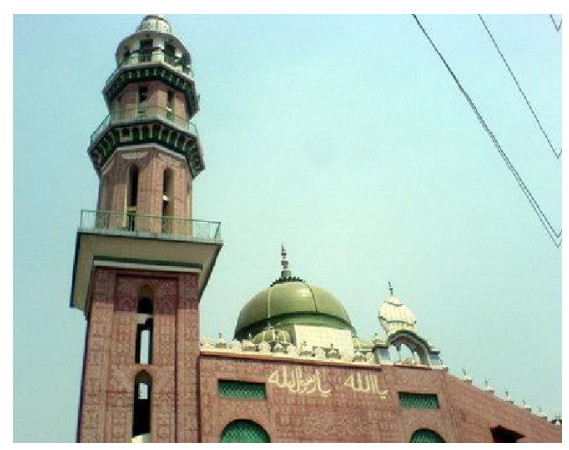

Figure 23: Jamia Masjid Gunj Bukhsh, Iqbal Park, Lahore

\section{Conclusion}

From the case studies of historic mosques, it is concluded that the historic mosques were magnificent and monumental in character. They had grand entrance portals and high platforms; domes were common in odd numbers, mostly three or five. The richly decorated double domes solved structural issues and were a great contribution to the overall ambience of prayer halls. The prayer halls were open with three or five archways. Large tiled courtyards were in practice with hujras around. Minarets were used in even numbers. They had different storeys and cupolas on the top. Staircases are found inside the minarets for access to the top. Ablution tanks or fountains are found in the center of the courtyards. Surface decoration has emphasis, normally done in fresco mosaics and pietra dura. Parapets were also decorated. Marble was used for cladding. Buildings were constructed with lime mortar and bricks. Blue, green and yellow colors have been used for decoration. Calligraphy was also found in surface decoration patterns. Geometric and floral patterns were used in decoration panels. Use of muqarnas was found in arches and entrances. Decorative columns and multi-foil arches were also found.

The general overview of the history of post-independence mosque architecture leads to the conclusion that there were a few, rare examples of specially designed mosques and large number of mohalla mosques. The reason for this was that the craftsmen who carried the Masjid-Nabvi inspiration with them, designed the mohalla mosques. Because of religious association, many pilgrims who perform the Hajj, the other pillar of Islam, went to Madina-al-Muwara to visit the mosque. The most prominent feature of the Masjid-Nabvi is the green dome that lies above the graves of Muhammad ( $S A W)$ and his companions. The dome was built in 1817 and painted green in 1837 . The point to note is that the green dome which is being copied is not the mosque area originally. Generally in our society, there are set teams of masons which get a contract of one building after the other and follow same style of construction and design. Therefore, we often see the same designs being used in many mosques. 


\section{References and Footnotes}

1 Farida Khanam, Life and Teaching of the Prophet Muhammad P.B.U.H: its Relevance in Global Context (Goodword Books, 2003), 26-41, accessed October 8, 2015, http://www.cpsglobal.org/sites/default/files/Life\%20and\%20Teachings\%20of\%20th e\%20Prophet\%20Muhammad_0.pdf

2 Allamah Sayyed Shah, Turab ul Haque Qadri, The Book of Prayer: Kitaab-ul-Salaat, 10, accessed December 1, 2015, http://www.ahlesunnat.biz/salaat.pdf

3 Sahih Bukhari, Volume 1, Book 11, Number 618.

4 This space is used at least twice a year as per Muslim faith.

5 Kendra Weisbin, "Introduction to Mosque Architecture," accessed December 10, 2015, https://www.khanacademy.org/humanities/art-islam/beginners-guideislamic/a/introduction-to-mosque-architecture

$6 \quad$ Nasim Ahmad bin Haji Karamuddin, Betullah Kabah Sharif: Qadeem haram sharifkiahd bah ahdtosehaur tamer (Pakistan, Faisal Publisher, 2013), 190-198.

7 S. Kamal Abdali, "The correct Qibla 1997), Accessed September 10, 2015, http://nurlu.narod.ru/qibla.pdf

$8 \quad$ Akel Kahera, Latif Abdul Malik, and Craig Anz, Design Criteria for Mosques and Islamic Centers: Art, Architecture, and Worship (USA, Architectural Press, 2009), 19.

9 Spahic Omer, "Some Lessons from Prophet Muhammad (SAW) in Architecture: The Prophets Mosque in Madinah" Intellectual Discourse 18 (2010): 118. Accessed September 15, 2015, http://irep.iium.edu.my/12874/1/126.pdf

10 Abbas Ali Farahati, "The Mosque as the First Political-Ideological Base in the Islamic Society," Journal of Politics and Law 4 (2011): 146-152. Accessed October 5, 2015, doi:http://ccsenet.org/journal/index.php/jpl/article/viewFile/7604/6881

11 Ahmed Nabvi Khan, Development of Mosque Architecture in Pakistan (LokVirsa Publishing House, 1991), 71-74.

12 Pietra Dura is a terminology used for inlay technique of using highly polished colored stones by cut and then fitted to create images.

13 Salman Muhammad, "Documentation and Conservation of Wazir Khan Mosque, Lahore, Pakistan." Accessed September 20, 2015. http://cipa.icomos.org/fileadmin/template/doc/PRAGUE/129.pdf

14 Mamoona Khan, Wazir Khan Mosque Rediscovered (Lahore: Pakistan Writers Cooperative Society, 2011), 271-274.

\section{Selected Bibliography}

1. Abdali, S. Kamal. "The Correct Qibla" Accessed September 10, 2015, http://nurlu.narod.ru/qibla.pdf

2. Ahmed, Imtiaz. Remainders for People of Understanding with Essential Details of Prophet's Mosque Madina Mukarrama, 2001.

3. Bukhari, Muhammad b Sahih Bukhari, Volume 1, Book 11, Number 618.

4. Farahati, Abbas Ali. "The Mosque as the First Political-Ideological base in the Islamic Society.” Journal of Politics and Law 4 (2011): 146-152. Accessed October 5, 2015. http://ccsenet.org/journal/index.php/jpl/article/viewFile/7604/6881

5. Kahera, Akel. Latif Abdul malik, and Craig Anz, Design Criteria for Mosques and Islamic Centers: Art, Architecture, and Worship. USA, Architectural Press, 2009.

6. Karamuddin, Nasim Ahmad bin Haji. Betullah Kabah Sharif: qadeem haram sharif ki ahd bah ahd toseh aur tamer-e-Pakistan [(Expansion of Kaaba Shareef and Pakistan) (Urdu)] Fasial Publisher, 2013. 
7. Khan, Mamoona. Wazir Khan Mosque Rediscovered. Pakistan Writers Co-operative Society Lahore, 2011.

8. Khanam, Farida. Life and Teaching of the Prophet Muhammad SAW: its Relevance in Global Context. Goodword Books, 2003. Accessed October 8, 2015, http://www.cpsglobal.org/sites/default/files/Life\%20and\%20Teachings\%20of\%20the $\% 20$ Prophet\%20Muhammad_0.pdf

9. Muhammad, Salman. "Documentation and Conservation of Wazir Khan Mosque, Lahore, Pakistan."Accessed September 20, 2015. http://cipa.icomos.org/fileadmin/template/doc/PRAGUE/129.pdf

10. Nabvi Khan, Ahmed. Development of Mosque Architecture in Pakistan. Lok Virsa Publishing House, 1991.

11. Omer, Spahic. "Some Lessons from Prophet Muhammad $(S A W)$ in Architecture: The Prophet's Mosque in Madinah." Intellectual Discourse 18 (2010): 118. Accessed September 15, 2015, http://irep.iium.edu.my/12874/1/126.pdf

12. Saqib, M. Abdul Karim. A Guide to Prayer in Islam, 16-17, accessed Nov. 12, 2015, http://d1.islamhouse.com/data/en/ih_books/single/en_a_guide_to_prayer_in_Islam.pdf

13. Shah Turabul Haque Qadri, Sayyed. The Book of Prayer: Kitaab-ul-Salaat, 10, accessed December 1, 2015, http://www.ahlesunnat.biz/salaat.pdf 